\title{
Rethinking Tracking Practices: What Teachers Say
}

\author{
Serap Yılmaz Özelçi ${ }^{1}$, Meltem Çengel ${ }^{2, *}$, Ruken Akar Vural ${ }^{2}$, Müfit Gömleksiz ${ }^{3}$ \\ ${ }^{1}$ Faculty of Education, Necmettin Erbakan University, Turkey \\ ${ }^{2}$ Faculty of Education, Adnan Menderes University, Turkey \\ ${ }^{3}$ Faculty of Education, European University of Lefke, Turkey
}

Copyright $\bigcirc 2016$ by authors, all rights reserved. Authors agree that this article remains permanently open access under the terms of the Creative Commons Attribution License 4.0 International License

\begin{abstract}
Under the different sides of discussion on the tracking, we attempted to understand how teachers and administrators evaluate tracking system in their school. We gathered data from teachers who employed in one of the government mandated schools in west part of Turkey. In this single case study, we collected data from 16 teachers, 1 administrator and 1 school counselor through the semi-structured interviews. The school that we gathered data has long term tracking experience on secondary level. We analyzed the data through a descriptive analyze method and discussed the results under the light of theoretical base. According to the findings, teachers usually define tracking as dividing students according to their abilities, intelligences, academic achievement levels or potential situations. The pros of the applications are improving upper class students' success, while the cons' are some of the psychological side effects and damages on students. Teachers also mentioned that relationship among classes is disconnected. And, usually there is more discipline problems in lower ability group class, while a teacher emphasized that there are different type of discipline problems in different ability classes.
\end{abstract}

Keywords Tracking, Ability Grouping, Primary Curriculum, Turkey

\section{Introduction}

Nowadays, most of us have been recalling the first concepts related to elementary school is "the set of the lazy ones and the hardworking ones". These concepts are sometimes constructed by dividing inside the class, or sometimes transformed into "the class of the lazy ones and the hardworking ones". Although all these concepts just seem innocent memories belong to school, they represent a complicated pedagogical phenomenon basically. This phenomenon is a practice called "tracking" which is sometimes named as a "method", "technique", or "process". Ability grouping is an administration of collecting the students regarding their academic achievement and other skills in homogeneous sets and arrange the teaching and learning techniques regarding to these sets [27]. Tracking, on the other hand, reveals itself a special form of ability grouping and students are educated by being divided for their qualifications. Tracking implies a permanent assignment to a sequence of courses for students at a certain ability level, while ability grouping allows students to move into and out of grouping assignments at any time given demonstration of new capabilities [21].

Tracking is the practice of dividing students into separate classes for high, middle, and low academic achievement levels. Although teachers and administrators generally assume that tracking promotes overall student achievement and all students will be better met when they learn in groups with similar capabilities, it is still paradoxical term of humanist pedagogy $[57,58,68]$. In the last three decades, there is an ongoing debate in educational research about tracking of students into different learning groups according to their perceived abilities [2,5]. Tracking in schools as a form of segregated provision based on previous performance has generated debate internationally $[6,30]$. Tracking practices conflict with personal and professional beliefs about quality or commitments to equality [15].

Tracking is seen as the best way to supply academic individual needs and to handle with individual differences. There are some authors who agree that by grouping students together who share the same learning capabilities will help them gain a deeper and meaningful learning experience [48]. According to them, tracking has been implemented as a way of providing all children better education whose need vary in population [16, 39]. This concept is also related with differentiated curriculum, which implies individualization and every student need different kind of curricula according to their ability or achievement level. A second assumption that leading to tracking is that less-capable students will suffer emotional as well as educational damage from daily classroom contact, interaction, and competition with their brighter peers. Lowered self-concepts and negative attitudes toward learning are widely considered to be result of mixed-ability grouping for slower learners [45, 61]. It is also widely assumed that students can be placed in tracks and groups both accurately and fairly. Tracking is emphasized 
particularly for high-achieving and gifted students' academic interests [12].

However, effects of tracking on psychosocial outcomes remain uncertain [5]. There are some people who believe that students need to remain at the same pace of learning as others their age because of social factors. They argue that less able students lose the opportunity to benefit from positive peer effects, and they argue that being labeled as less able communicates low expectations, which may become self-fulfilling [22, 63]. Furthermore, grouping and tracking rarely add to overall achievement in a school, but they often contribute and reproduce to inequality as well and contributing to the social reproduction of elite and underclass groups in society [12].Typically, it means that high-track students are gaining and low-track students are falling farther behind (Alpert \& Beckar, 2014 ). Also, research on general and domain-specific academic self-concepts has shown that the average achievement of the learning group (e.g., class or school) influences students' self-image [e.g., 40, 44, 47]. Therefore, the effects of ability grouping on academic self-concept are therefore usually negative for highly able students and positive for lower achieving students [e.g., 26, $46,62,65]$.

Administrations of ability grouping and tracking were legalized after a suggestion of "dividing students into different groups in some subjects" in elementary school curriculum of 1968 in Turkey [17]. It was followed by the curricula of 1995. This dividing was suggested to be used in mathematics and Turkish courses [51]. However, there was no expression regarding "tracking" in the elementary school curriculum of 2005-2006 academic year and it was not suggested to apply this procedure.

These practices seem to very old when its Western history is examined. At first, tracking system was arranged by a teacher with the aim of using the time effectively during the class and helping the students for their needs [55]. Starting with the literate and illiterate students, later this division was affected by economical and industrial changes, and increased and varied with the given preference to raise the needed labor force aimed by the schools [42].

It is possible to state various different reasons and criteria regarding the emergence of administration of tracking. Basically it is asserted that ability grouping ease the teaching process and every student benefits from educational facilities as he or she needs via this practice $[19,22,33,34,41,56]$. On the other hand, there are also studies revealing that the practice mediated bringing the students having low socio-economic status together and providing them less education in low ability classes via employment of inexperienced teachers or less comprehensive courses $[6,8$, $33,42,50,53,66]$. While there are lots of studies investigating the effects of tracking system on students' academic and affective qualities $[1,5,6,7,11,13,14,27,29$, $31,34,35,36,38,41,60,63,64,69]$, there is only one research [27] examining teachers' opinions which are active agents in these practices and sometimes decision makers. In the light of these findings, the current study was focused on a school using tracking system, and a comprehensive investigation was done through the opinions of class and subject teachers.

\subsection{Aim of the Study}

The main aim of the study is to determine teachers' opinions about "tracking" system applied in their elementary school. Through this basic aim, answers for the following questions were searched:

What are the elementary school teachers', subject teachers', school counselors' and school administrators' opinions regarding to

1. the meaning of the concept of tracking class (level class),

2. strengths and weaknesses of tracking system,

3. whether this application is serving to raise the labor force the society needs or not,

4. the effects of tracking on friendships?

\section{Materials and Methods}

\subsection{Design of the Research}

Design of the current study is based on a case study as a type of qualitative research. Case study is defined as a detailed investigation of a key phenomenon, event or a situation serving as a model [24]. This study is regarded as case study due to focusing on class and subject teachers', school counselors', and school administrators' opinions in only one school. This school that was regarded in this case study is a public school having high mean of successful scores in Aydın, which is a city in the west part of Turkey. Tracking system was applied by considering students' 5 th grade scores in their transcripts and according to their transcripts, low, middle, and high level classes were created.

\subsection{Participants}

Participants of the study are 11 subject teachers, 4 elementary school teachers, 1 school counselor, 1 school administrator, and an assistant director of II. stage elementary school while also having a duty of being a class teacher, from a school where tracking system is applied. Maximum variation sampling was used to select participants as a type of purposive sampling.

\subsection{Measurement Tools}

Data were collected via "Semi-Structured Interview Forms" created by researchers. Interview forms were constructed after examining related studies $[18,28,36,60$, 63]. Interview forms were developed into some phases in the study. At the first stage, informal interviews on ability grouping between classes were conducted with teachers and 
students. At the second phase, preliminary interview forms were sent to two experts who are already led a studies on ability grouping. At the last phase, feedbacks were evaluated and final versions of interview forms were composed by researchers. There were parallel but in different number questions were settled in the different interview forms given to teachers, school counselor, principal, and students. There are 29 questions in subject teachers' interview form, 18 questions in school counselor's interview form, 11 questions in class teachers' interview form, and 21 questions in school principal's interview form. At the all stages of developing instruments, literature reviews were done by researchers/ authors. As Miles and Huberman [52] quoted concepts defined ahead by researchers, complex, multilevel, overloading cases need a lot of detailed instrumentation. That's why detailed set of questions were processed for data collecting. In addition, detailed interview forms lead to get detailed data and support internal validity in qualitative research.

\subsection{Collecting Data and Analysis}

Interviews occurred one to one in various places of the school. Duration of interviews varied regarding to type of forms used. They took approximately 45 minutes for subject teachers and school counselor, 15 minutes for class teachers, and 40 minutes for school administrator. In most part of the interviews, voice recorders were used and notes were taken. In school garden, however, only notes were taken considering the noise around.

For the analysis of data collected via interviews, descriptive analysis as types of qualitative analysis techniques [32] was used. Answers gathered from the interview questions analyzed in 8 different categories. During the process of creating a report of qualitative data, reliability was increased by quoting the exact interviews related with findings. Gender of quoted individuals mentioned in parenthesis. Another way of increasing reliability is triangulation $[49,52]$. The current study used analyst triangulation which is described as using multiple analysts to review findings [55] by researchers. For this process, two researchers scored the texts separately and then internal consistency was examined between the analyses. The situations examined under different categories were discussed and tried to be agreed upon them by using "agreed/ (agreed + not agreed)" formula to calculate the agreement between the researchers [52]. In this study, internal consistency between the researchers was found as. 92. In this research, respondents' names were excluded and given codes to present data such as CT for class teachers, ST for subject teachers, and SA for school administrator. At the data collecting process, same interview forms were used by three researcher/authors for providing consistency among researchers.

\section{Results}

\subsection{The meaning of the Concept of Tracking (Level Class)}

The answers of the questions "What does the tracking (level class) mean for you?" and "What does the concept of tracking evoke in you?" asked to 11 subject teachers for the perceived meaning of tracking as a concept examined. The answers focused on "classifying the students" as observed. Six teachers defined tracking as classifying students regarding to their success, 2 teachers regarding to their capacities, 1 teacher regarding to their knowledge, 1 teacher regarding to their intelligences, and another teacher defined the concept as separating hardworking and not hardworking students. Examples of subject teachers' opinions about the meaning of tracking mentioned below:

ST: It's separation of the student in terms of his/her knowledge, behavior, ... in fact, behavior is not taken into consideration so much, it's separation regarding to his/her knowledge... without looking the behavior. If behavior was taken into consideration, different students could have been in different classes (Male).

ST: It creates an impression of classifying the students. (It's) Grouping the children regarding to their intelligences, in the way of the best, middle and the worst classes. However, after looking the previous experiences of that practice, we don't do that anymore. There is no such thing in classes of this year (Female).

ST: (It's) Gathering the same level of students. (It's) Examined in terms of the achievement, not for the person, such as low level, high level (Female).

School counselor stated her opinion in that way:

SC: Tracking means that classifying students regarding to their achievement. (It's) Gathering good, middle, and willingly or unwillingly, bad students in a class. Generally the criterion is academical achievement.

Class teachers' opinions about the meaning of tracking were similar to subject teachers' opinions. One teacher defined tracking as "groups of level" (Male), another defined as "educating children regarding to their capacity and level" (Male), and two teachers defined as "classifying children regarding to their academic achievement" (Male, Female).

CT: Groups of level is educating children regarding to their capacity and level. Intelligence, environment, demographical background determines their levels. In first stage, class of a level is definitely not created. It only be created at 6th, 7th, and 8th grades, but it cannot be done at 1st, 2nd and 3rd grades. Different practices can be given to children in class without making understood, though (Male).

Teachers' opinions about the meaning of the concept of "tracking" summarized below: 
Table 1. Meaning of "tracking"

\begin{tabular}{ccccc}
\hline & $\begin{array}{c}\text { Subject } \\
\text { teachers }\end{array}$ & $\begin{array}{c}\text { Class } \\
\text { teachers }\end{array}$ & $\begin{array}{c}\text { School } \\
\text { Adm. }\end{array}$ & $\begin{array}{c}\text { School } \\
\text { counselor }\end{array}$ \\
\hline $\begin{array}{c}\text {... success /academic } \\
\text { achievement }\end{array}$ & 6 & 2 & & 1 \\
$\ldots$ capacity & 2 & 1 & 1 & \\
$\ldots$ knowledge & 1 & & & \\
$\ldots$ intelligence & 1 & & & \\
$\ldots$...hardworking & 1 & & & \\
$\ldots$ groups of levels & & 1 & & \\
$\quad$ Total & 11 & 4 & 1 & 1 \\
\hline
\end{tabular}

\subsection{Strengths and Weaknesses of Tracking}

Examination of answers of subject teachers' opinions about strengths of tracking revealed that teachers emphasized this practice increased academic achievements of especially high-level classes (five teachers). One teacher expressed that they reached their goals in shorter time, two teachers stated that this practice created educational opportunities which are appropriate to child's level, one teacher declared that employees are raised as society needed via tracking, another reported that this application is parallel with others done by Turkish Educational System, and other claimed that if there was an opportunity to change students' classes constantly, it would become a motivating application for students.

Regarding to answers given for weaknesses of tracking, basically the answers focused on that the students in low level classes are negatively affected psychologically by the application (six teachers). Besides this focus, one teacher stated that they cannot do lessons efficiently in low level classes, another added that the competition in high level classes affects students' friendships, one reported that more effort should be put to reach goals in low level classes, other told that teachers' motivation is very low when they do lessons in low level classes and students' behavior problems increase in these classes due to that there is no role model for students, sometimes high-level classes humiliate and give name to students in those classes, and another teacher expressed that this application created discrimination and it will create unwanted results for public dynamics.

Some of the answers regarding the strengths and weaknesses of tracking reported by teachers are mentioned below:

ST: If the classes are changed constantly, there may be an advantage of it. If the child knows his/her class will be changed, s/he may put effort to move up to next class. I think its disadvantages are more than its advantages on the child's psychology, though. There is no such thing in pedagogy. In anyway, a successful student is successful. There is no his/her upper position. S/he will compete with his/her own class. If there were any other students unsuccessful, there might be children wanting to study by looking at them. Yet, feeling of being excluded, that "I'm lazy" occurs in children when they are in a separate class. For instance, it happened so much in 8th graders of this year (Female).

ST: Everything has a good side and a bad side. It's a very good practice for good classes. Their performance increases. They are ambitious. They compete intensively. Yet, these affect their friendships negatively. After the exam, the child asks not his/her own grade, but his/her competitor's grade. S/he says "how I got 92 when he got 95?". It affects the achievement of bad classes. They become more unsuccessful. Good classes cause complex in other classes. There are grade obsessions among children in good classes. They constantly study to get 100. They ask "why my grade is not 100 ?" every time (Female).

School counselor expressed her opinions about this subject as below:

SC: Their weakness is learned helplessness. It is too hard to motivate them regardless what you do. Colleagues (teachers are referred) make comparisons. It causes so much harm. Its (tracking) strength is, (providing) more comfortable class atmosphere and more number of questions for the students in middle or good level classes. However, there is pedantry and arrogance in these children. They see themselves as superior. We experience behavior problems among 8th graders much in these days. There are no academic problems. The luckiest children are the ones in middle class now. Last year, one of my students did not move to upper class even s/he could do it. They are so harsh to each other. We see that in interviews with the children. They react us even when we arrange trips, by saying "why do you start with this and that section?". Thus, they have feelings of incompetence, and being excluded. Regardless how much you have talked to them, you cannot change it. I start with low level classes for trips. I give responsibilities. I give duties with safety uniforms, emblems, etc. on 23th of April. They are the most tired ones, but they become so happy.

Four class teachers expressed their opinions as below:

CT: Some children became withdrawn. Although the child must have been in a good class, s/he could not move there after the exam. S/he had been withdrawn for two years. Children in the best situation were the top ones of the class. I think they lose their selves. The group culture of the class cannot be created in 10-15 days, because solidarity occurs on 7th-8th day. Yet, the conflicts with other classes happen (Male).

CT: As I am the class teacher, students come to me to take my opinions in every subject. Yet I observed their unhappiness when they come after tracking applied. They say, "Teacher, they said that I am lazy!", "Come on my child, it is not true!", "But, they said I cannot go to that class, can I?" (Female).

Besides these, a class teacher reported that there is no weakness of the application, and another stated that there is no strength:

CT: Here I totally decided that, my priory graduated students were classified ones, this year I will make another classified ones graduate, definitely and certainly, indisputably, it is not correct. I understood that better due to that I am the class teacher of 8-B. I understood that better 
from children's reproaches, discomforts, and psychological conditions. It is not a good thing. It is not a good thing to discriminate for the sake of society. More particularly, discriminating in the setting of education is definitely not a good thing (Male).

CT: I don't think that it has a bad side. I think it is positive. When we look at the education system in Europe, for instance Germany, there are gymnasiums. They are equal to science high schools here. Germans do that. Students going these schools create the upper class of Germany as bureaucrats, engineers. Others going to normal high schools have simple jobs such as bank employers, etc. In Turkey, workers in banks are usually graduated from engineering studies of top schools but they do not their jobs while going to banks and work there. Turkey is totally a country of coincidences but Europe does this (Male).

School administrator referred to some of strong and weak points of the practice as below:

SA: We experienced the drawbacks of the practice stemming from the teachers or parents. Let's say three classes, 8-A, 8-B, 8-C. 8-A is the best class, 8-B is the lowest class, and $8-C$ is in the middle. Teacher of $8-B$ can be offended by stating "why these children are with me?", as an example. It could be different if s/he communicates with those children in their languages, or behaves to win them. Yet, the same is necessary for teacher of 8-A, I mean, the students there are the good ones, but they need a special interest, too. In this case, guidance, school counseling, teaching is important. You should not let everyone become teachers. You should not let everyone become administrators, too. You should discard me. You should examine my psychology, is it intact, or not? Am I a schizophrenic, or not?

Teachers' opinion about strengths and weaknesses of the application is summarized below:

Table 2. Strengths and weaknesses according to subject teachers

\begin{tabular}{|c|c|}
\hline Strengths & Weaknesses \\
\hline $\begin{array}{l}\text { increased academic achievements } \\
\qquad(\mathrm{f}=5 \mathrm{ST})\end{array}$ & $\begin{array}{l}\text { Students in low classes negatively } \\
\text { affected psychologically (f=6 } \\
\text { ST; } 2 \text { CT, 1SC) }\end{array}$ \\
\hline $\begin{array}{c}\text { increasing educational } \\
\text { opportunities }(\mathrm{f}=2 \mathrm{ST}, 1 \mathrm{SA} \text {, } \\
1 \mathrm{SC})\end{array}$ & $\begin{array}{l}\text { Can not do lessons efficiently in } \\
\text { low level classes' (f=2 ST) }\end{array}$ \\
\hline $\begin{array}{c}\text { reaching goals shorter time }(\mathrm{f}=1 \\
\mathrm{ST})\end{array}$ & $\begin{array}{l}\text { Competition in high level classes } \\
\text { affects students' friendship ( } \mathrm{f}=1 \\
\text { ST, 1 SC) }\end{array}$ \\
\hline $\begin{array}{c}\text { employees are raised as society } \\
\text { needed ( }=1 \mathrm{ST})\end{array}$ & $\begin{array}{c}\text { Teachers motivation low in low } \\
\text { level classes, (f=1 ST, } 1 \mathrm{SA})\end{array}$ \\
\hline $\begin{array}{c}\text { parallel to education system }(\mathrm{f}=1 \\
\text { ST) }\end{array}$ & $\begin{array}{l}\text { No role models in low classes } \\
\qquad(\mathrm{f}=1 \mathrm{ST})\end{array}$ \\
\hline $\begin{array}{l}\text { if there was an opportunity to } \\
\text { change students' classes } \\
\text { constantly, it would become a } \\
\text { motivating application (f=1 ST) }\end{array}$ & $\begin{array}{l}\text { Humiliation and giving names to } \\
\text { classes, creating discrimination } \\
\text { (f=1 ST; } 1 \mathrm{CT})\end{array}$ \\
\hline No weakness (1 CT) & No strengths (1 CT) \\
\hline
\end{tabular}

\subsection{About the Claim of that Tracking Makes Addition to Raising the Qualified Labor Force Which Society Needs}

Five subject teachers agreed with the opinion that tracking makes addition to raising the qualified labor force which society needs. One of those agreed teachers pointed out that the education system is already separating with the exams of such as Anatolian High School, Science High School, and the practice in the school is a little model of that general administration.

ST: Yet the state already does this with its own examinations. It encourages this in any way. It takes its needed brain team from science high schools. The state already does this in other high schools as well (Male).

ST: In fact, it can be correct. It can be rational. The ones in the best classes have high goals. Such as science high schools, Adnan Menderes Anatolian High School, and so on. They see themselves as they are superior. I made them write an essay asking their goals, expectations from the life. They have such goals like being the best heart surgeon in the world. The others have no goals. They don't know what they do. They spend their time aimlessly. The good students in bad class try to leave from there (Female).

ST: Correct. The students left are better, they are the ones who can reach better places, but it depends, still it might change in the future (Female).

However, four teachers do not agree with this opinion regarding with the tracking. While a teacher expressed that there is no need for tracking to create this labor force, other stated that there is already a separation made via the exams of Anatolian High Schools and Science High Schools, elementary education is early for such an administration. Another teacher added that this practice focuses on the teaching of particular subjects rather than raising qualified people needed by society. Also, a teacher's opinion is that as tracking is an application focused on exam achievement, it does not make an addition to raising the qualified people needed by society.

ST: When you exclude everything like student's psychology, thinking only in terms of achievement -we say it as "to become a robot" with students, this application is very nice. Of course, it makes one reach that goal. However, it is not the goal anymore. It is not the expected student model in society anymore. We see that in the new curriculum, too. Let me give an example from my course, being knowledgeable about verbs, nouns, adjectives is not the only expected thing for a child anymore. The aim is to raise a child who is reading, commenting, aware of the world which does not need tracking anymore (Female).

School counselor's opinion is that tracking does not service for raising the people who have the needed qualities by society.

SC: A system having a prepared substructure is necessary. Vocational technical education is deplorable. Children do not want to go there. It does not provide further facilities. Owing to that, I cannot advise vocational education to 
parents. Intermediate members are needed. Yet, substructure is not ready. Also, grouping according to parent's jobs was never made, while there are some schools arranging groups according to their status. This is huge inequality. The people whom society needs cannot be raised in that way.

School administrator expressed his thoughts as below:

SA: In this system, what everyone wants is their child would become the best. Yet, are the five fingers of a hand same? No, of course each child's abilities, intelligence, emotions, thoughts are different. Though, yesterday there was Ziya Baran's "Fast Reading Techniques and Concept Maps" conference we went. While computer operator was writing behind him and projecting 30 idioms to cinevision, Baran told these 30 idioms almost without looking at there. Then you say by mixing their order, he also tells them. This means he creates their shapes in his mind as concept maps. How many people in Turkey can do that? I mean, I can do it, you can also do it but we need training for that. Of course all of our children will become doctors, judges, prosecutors, teachers, machinists, farmers, salespeople... everything they will become. In fact, our education system provides a regulation according to that but everyone targets science high schools nowadays. Everyone targets Anatolian high schools. Everyone targets to become a doctor, judge, engineer. This is not possible, though. I'm looking at my own children, I forced my daughter to make her a nurse. Now she complies about it. She was such a great mathematician. The system in those days put barriers on her (Male).

Teachers opinions' about "tracking makes addition to raising the qualified labor force which society needs" is summarized below:

Table 3. Tracking makes addition to raising the qualified labor force

\begin{tabular}{ccc}
\hline & Agreed & Disagreed \\
\hline Subject teachers & 5 & 6 \\
Class teachers & 1 & 3 \\
School Adm. & 1 & - \\
School Counselor & - & 1 \\
\hline
\end{tabular}

\subsection{Regarding to What Extent Tracking System Provides Educational Facilities for Students' Abilities}

All of nine subject teachers answered the question of "Do you think that educational facilities are provided to students regarding their abilities with tracking system?" expressed that it does not provide such an opportunity. Seven subject teachers expressed that only academic achievement but not the abilities considered as a criterion in tracking system. When answers were examined, regarding academic achievement is thought to be based on Turkish language, science, social studies, and English language courses. Therefore, teachers state that students are not divided by the courses revealing their ability but their academic achievement in specific courses.
ST: No, their abilities are not taken into consideration. Painting, music, sports, etc. are not examined (Female).

ST: Nowadays while preparing the level classes, abilities are not examined but their achievement in basic four courses. Not the abilities. When I say ability, proclivity to painting, music, arts or social studies, science, etc. comes to my mind. Yet, these were not considered while creating the level classes. Thus, ability is not regarded, it is a different subject (Female).

ST: No, this kind of arranging is not possible in elementary school. For instance, why my course is just 1 hour in a week? What can I do in that 1 hour, should I detect how talented a child is, or give points, which one should I do? Which child should I pay attention to (Female)?

Moreover, two subject teachers mentioned that the same teachers give courses of different levels and do the subjects similarly which causes the students not taking education regarding their abilities.

ST: I think it won't provide. I don't know exactly. Actually, equal opportunities are provided in our school. We didn't give different teachers to $A$ and B classes. Everyone taught their subjects in every class in the best way they can do, only there were some differences in terms of processes of courses (Female).

ST: Everyone is provided the same opportunity, not different. There is nothing differently taught (Female).

School administrator expresses his opinion as below:

SA: Now we changed our system into classrooms in our school. Now we have computers, cinevisions and projectors in Mathematics 1-2, Turkish Language 1-2, English Language 1-2 and Science Laboratory. Additionally, next year, I mean, this year, we put an interactive blackboard in Mathematics classroom. In other name, smart blackboard it is. Now in all three 4th grade and 3rd grade classes, there are smart boards. Next year, we will put computers and cinevisions to three classes in 2 nd stage. Let's say a child in $A$ class. 6-A, 6-B, 6-C have the same mathematics teacher, same Turkish language teacher. Even when teachers change, something like "you gave good teacher, bad teacher" is out of question. When teacher comes in, the facilities are same in every class s/he uses. I mean, there is nothing like "he sat on a comfortable chair, I did not", "his computer is the most recent one, mine is old". We provide the same quality, same facilities to everyone.

Teachers' opinions about "Do you think that educational facilities are provided to students' regarding their ability with tracking system" are summarized below:

Table 4. Educational facilities are provided to students' regarding their ability

\begin{tabular}{ccc}
\hline & Agreed & Disagreed \\
\hline Subject Teachers & 2 & 9 \\
Class Teachers & 1 & 3 \\
School Adm. & - & 1 \\
School Counselor & - & 1 \\
\hline
\end{tabular}




\subsection{Characteristics of Relationships between Students in Different Classes}

Five of the nine teachers stated that the relationships between students in different classes are "poor" or "disconnected" while answering the question of "How are the relationships between students in different level classes?"

ST: It's disconnected. Previously it was said that "go to your class" to Class A's students. They are children, naturally they are spoiled... Yet, I intervened to their talk like this. Such bad talks were happened obviously. Standing off from the students of other classes was happened. However, most of these children are in the same after-school support centers, they are together in school, their parents are seeing each other in their homes. I mean, this disconnectedness would also happen without level classes (Male).

ST: I say something, in the graduation party; students of 8-C and 8-B did not want to be together. They did not want a party occurring on the same day. This reveals the gap between them. Think the students of $A$ when Bs are like this. With this kind of separation, they are clamped together (in their classes), but they did not make any interaction with others. They become clamped together against others (Male).

ST: It's very bad. Naturally there will be the feelings of superiority, just like saying that our level is a bit, a little lower than other class. There is no interaction between them, I observe that. S/he does not know her/his friend's name, even in 8th grade, as an example. They are three classes at total. A student in Class $C$ does not know the name of another student in Class A, for instance (Female).

A teacher (Female) mentioned that "there are students who have continuous relationships with the students of other class, and also there are some do not have that", another teacher stated that they are harmonious in their own classes, other added that they embrace their classes in time, and also another declared that their relationships are well between different classes.

ST: There is not much discrimination. Due to that they were in the same class for 5 years, they wait each other near the door during the break (Female).

ST: There were some students continuing their friendships began in the first five years, but there were some humiliating others, do not speak to them, saying "you are lazy, we do not talk with you" even as a joke after changing their classes. $Y e t$, it is not possible to generalize it, there were some coming to us complaining like "Teacher, they say this and that to us" but they were 4 or 5 students (Female).

School counselor's observation about students' relationship with each other as below:

SC: There is not so much interaction between each other. It changed accordingly the results of their exams. The 6th graders of this year are better. We applied two exams in the first administration and changed the groups but later the City Administrator of National Education removed them.

School administrator comments on this subject as below:

SA: The relationship between the students of different classes, but we experience the problems inside the classes. Especially this year, we wondered that whether it was due to their developmental period, adolescent years. This year we saw more, children tried to impede each other rather than competing. Especially clever, good students did that. We could not find a solution to that, with guidance service, or administration, though. This year is especially harder for me. There are harms on wooden chairs of school costing 2 billion Turkish liras. Children inscribed on desks, wrote names. It is not a place for that, for instance. We did a school night. We did decoration costing 450 million liras. Children said that "Can we pop the balloons?". I said, "Help yourself." All of the graduating children broke them into pieces as if they went to a war, with vindictiveness, like taking revenge. And I said to myself, we do something wrong to those children, because children are filled up with stress all the time. What will you say, exam stress, or grade stress, put a name on it, I won't do that. But now, we don't give anything to children to make their energy, their effort be consumed. Child cannot do a box match, wrestle, or swim properly. All the time courses, courses and courses, exams, exams, and exams, grades, grades and grades. I am not the responsible one for that. Yet we are one of the best schools in Aydin in terms of students' behaviors, I mean, according to my observations. Maybe we are not the best, but we are among the best ones.

Teachers' opinions about relationships between students in different classes are summarized below:

Table 5. Relationships between students in different classes

\begin{tabular}{cccc}
\hline & Poor & Well & $\begin{array}{c}\text { It can be } \\
\text { change }\end{array}$ \\
\hline Subject teachers & 5 & 5 & 1 \\
Class teachers & 4 & - & - \\
School Administrator & 1 & - & - \\
School counselor & 1 & - & - \\
\hline
\end{tabular}

\subsection{Whether the educational process differs among the different levels of classes according to subject teachers', class teachers' and school administrator' opinions}

All subject teachers except one of them mentioned that there are differences between the high level class and other classes in terms of educational process. While two of the teachers expressed that they simplify the teaching in lower classes, four teachers stated that there are differences in terms of the number of questions and their difficulty levels, one added that $\mathrm{s} / \mathrm{he}$ consider the differences between classes while arranging the activities, another declared that there are differences among the different levels of classes in terms of the time spent to teach each subjects.

ST: It shows differences from time to time. I sometimes give the same examples. But especially in the better class, if the children can accomplish them with their prior knowledge, I give examples harder to comprehend without covering next 
grades' topics (Female).

ST: I give more complex examples at 8 a expecting them to solve the questions. I follow through harder questions starting from easier ones in $8 b$. I only give easy examples at $c$. They reach to the solution after several steps in $8 a$. The question of the topic comes immediately. The children surpass my flow sometimes (Male).

In different level classes, not only the amount and difficulty of the covered questions, but also the disciplinary problems and class atmosphere in the same lessons differentiated the classes. A teacher pointed out that there are different problems in different levels whereas 7 teachers stated that the main problem in lower level classes is disciplinary ones.

ST: There are disciplinary and behavioral problems in the classes we label as worse. There are both outside of the class, between the peers, and in the class problems through disturbing their desk mates (Female)

ST: I do not experience it in b. I experience it very little in $C$. The class with the most frequent problems is a. The children can get distracted easier as they give up. The problem is not disrespect but pertness, levity, and not listening to the lessons (Male)

ST: I do not experience disciplinary problems. I experience problems in $8 B$. There are no notebooks or books. The come and go. I cannot provide enough supply through giving pencils or notebooks. They find coming to school meaningless or empty. We experienced several problems in these terms with $8 A$. They perceive themselves as superior. I experience problems with $8 C$ (Female)

Three class teachers stated their opinions about the topic as follows:

CT: children in upper lever classes force the teacher to explain more elaborative as they investigate and question, which is natural. This is what should be (Male).

CT: I do not think there is such a thing. But it may be conducted unintentionally in practice. There is no point bringing an upper level experiment to a lower class. The children cannot understand regardless of your actions (Male)

CT: Prejudice. It is the good class- bad class thinks the teacher. The teacher thinks how to spend one hour as s/he enters the class. S/he enters the best class feeling contented, enters reluctantly to the others (Male)

The school administrator stated his/her opinions about the topic as follows:

SA: Now I enter the lessons. I mean I accompany one of my teacher friends in his/her class for 3 hours or 5 hours. The teacher meets my expectations about his/her performance when I am present. I... Being a teacher is such an occupation that it's about dignity. Do you sleep without a clear conscience because of the endeavor I made, or the things you have did? Don't you? This is the point.

Teachers' opinions about if "educational process differs among the different levels of classes" is summarized below:
Table 6. Educational process differs

\begin{tabular}{ccc}
\hline & Agreed & Disagreed \\
\hline Subject teachers & 10 & 1 \\
Class teachers & 3 & 1 \\
School administrator & 1 & - \\
School counselor & 1 & - \\
\hline
\end{tabular}

\subsection{Attitudes of Teachers towards Students and Lessons in Different Level Classes According to Subject Teachers, Class Teachers, and School Administrator}

A teacher stated that there is no difference between the different level classes, whereas nine teachers stated that teachers' attitudes towards students and lessons differentiated between the classes. According to teachers, the main reason for teachers' different behaviors in different level classes is that the structures of these classes are quite different than each other. The teachers highlighted that "they make more effort" (Male), "they feel nervous because of the possibility of missing the due time of the topics" (Female) especially in the lower level classes.

ST: Yes. I think, even the ones that claim they do not do, they do not explain differentially, they consider that now I go this class, oh what will I do, how will I spent 40 minutes as they go to the class, even without reflecting it to the children. But we try not to reflect it to the children. It happens in our minds. Let me give an example from myself. I try to behave fairly as much as I can but sometimes I happen to say "children, I solved this question in the other classes as well, it is not that hard." Even if I claim never doing it, this is the most innocent one. Sometimes now we leave professional aspect we are human beings too it is reflected. But I am sure that there are people doing more serious things than this.

ST: of course there is, isn't it? I enter $6 A$ and shout more, I enter $6 C$ and shout less. The child behaves in that way. 2-3 of them are unconcerned. It is needed to gather their attention. Of course I raise my voice. There is one called Ayşegül who does not sit. It happens more at 8th grades (Male).

ST: The community of students effects the teacher too. The teacher's behavior may be different especially in the middle classes. But this arises from the students. I do not think so (Male)

ST: Let me talk from my own terms. I mean, there are times that they push our patience. But you try to overcome these obstacles somehow (Female)

ST: It is reflected naturally. Now there is such a thing. When you cannot lower yourself to their level, which is difficult in some lessons. I mean there is no need to give names. Now it is indicated in the curriculum that such conditions will be generated, or drawed. The teacher tries to accomplish these conditions. In the good class, which is A, the teacher draws, they draw. In the other class, you need to try again and again and again. This instinctively reflects tiredness, or negative behavior, or a negative behavior 
against this class to the teacher. Sure, this depends on the teacher's conscience level. This happens; I cannot say it does not (Male).

Teacher: I did not see. It has never happened. This class can strain a human sometimes. You spent so much effort. I can say that this class strains, becomes hard (Female)

The school counselor stated her opinions about the topic as follows:

SC: I have never observed this. The teacher enters the class aiming not to become angry, and to motivate. But s/he unavoidably starts being angry. Or s/he enforces children to change their behavior. I think they do not enter classes biased.

One class teacher expressed her opinions about the question as follows:

$C T$ : there is not a big difference. The teacher friends here do not hinder the lecture discriminating between the classes. Because the topics covered in the good class are all present in other classes as well (Male).

Opinions of the school administrator about the question can be stated as follows:

SA: Unfortunately. I mean the problem is this. The source of the main problem is this. For instance a teacher says in the past years. We get graduated 8th grades this year. The newly arrived teacher complains "the children in $7 B$ do not comprehend as good as the children in $7 A$. So I do not want to enter the lessons of $7 B$." Yet we know that the children cannot comprehend as good as them. Yet this is our aim. But the new teacher does not internalize this spirit of mine in that day. When they do not internalize it, your efforts go for nothing.

Teachers' opinions about if "attitudes of teachers towards students and lessons may differ among different levels" is summarized below:

Table 7. Teachers' attitudes differs

\begin{tabular}{cccc}
\hline & Agreed & Disagreed & Not stated \\
\hline Subject teachers & 9 & 1 & 1 \\
Class teachers & 2 & 2 & - \\
School administrator & 1 & - & - \\
School counselor & - & 1 & - \\
\hline
\end{tabular}

\section{Discussion and Conclusions}

In this study, it has been tried to be determined the teachers' and school administrators' opinions, experiences and evaluations about "tracking" system in a school in which "tracking" system is applied. According to the general view of the teachers and school administrators, students of the tracking courses concept are seen as "categorizing in line with certain aims, and according to the certain standards". Those standards dealing in these classes diversify as successes, capacities, knowledge, intelligences, and working situations of students. This definition is in parallel with the definitions in the literature $[10,22,23,37,54,66,69]$. When the strengths and weaknesses of this application were evaluated by the implementers, the prominent strength was increasing the success of students who are in a higher success group, and the prominent weakness was affecting students in a negative way psychologically. In the literature, such emphasizes were also encountered. Gilles [25] stated that categorizing students according to their abilities affect students especially in a "lower" ability group negatively. In the lower level classes, there is no positive role model for the students, and accordingly learning level decreases with the teachers who have lower expectations $[6,53,66]$. According to Cheung and Rudowicz [14], in the level based clusters, (with the anticipations of schools, teachers, or education authorities) regulations are made without considering the fact that abilities of students have been shaping by their personal preferences, decisions of parents, economical statuses, interests of other personal characteristics, historical and cultural reasons, and period of change. On the other hand, according to Argys, Rees and Brewer [3], level based clusters are based on an application in which "winner" and "loser" individuals are created, whereas it is an application which is implementing in the local schools in which minority groups inhabiting and those students are placed to the lower level classes according to Braddock [9]. In the light of these findings, it has been come into view that evaluating the effects of this application especially on the students who are in the lower level classes is an important necessity.

Moreover, all the teachers who were answered the question "Do you think that students are provided an education opportunity that in line with their abilities by means of level based classes?" claimed that this application does not provide such an opportunity that in line with their abilities through the level based classes. Similarly, there is not a supporting view such that level based class application contributes to bring up manpower in different qualities which is needed by the society. When the views of teachers in this topic were examined, whereas five of teachers emphasized that this application is already similar to dividing students to different high school types, four of teachers disagreed with them. According to Nevi [56], students' socio-economic statutes, interests, abilities, and attitudes are different. These genetic differences have not been created by schools. Schools should classify students in terms of their interests and abilities. Through this way, it is aimed to meet each individual's needs, and accordingly to increase the academic success [20, 22, 33, 34, 41]. This point of view definitely shows us the underlying implicit philosophy beyond the level based classes. In this way, step-by-step explaining and slow-going programs for the lower level students; and fast, comprehensive and elaborate programs for higher level students are suggested. Through examining them, level based class applications can be considered as servicing to bring up manpower which is needed by the society. Whereas students in higher success levels are prepared for the further educational institutions, through directing students in lower level clusters to vocational education, not only the need of manpower is 
fulfilled, but also those students receive education in line with their abilities. This situation reflects the class theory at the same time. In the studies of Hallam, Ireson and Davies [28], the findings revealed that although the students are divided into level based classes according to diverse variables, teachers generally teach tempering to an "average student". From this point of view, characteristics of students and teachers factor can be thought as more effective than "implementing styles". On the other hand, according to Cheung and Rudowicz [14], the fact that students in higher success levels receive education in "good" schools is not an example of "level cluster application", but a product of an educational gap. This condition is observed more intense especially after students are placed in classes when the situations do not allow mobility.

Teachers claim that academic success is generally effective in determining which students should continue in which level based class. There are some teachers who state that class point averages of fifth grade or school report point (four teachers) are used as a criterion of academic success. Also, there are some teachers who state that Placement Tests implementing by the Ministry of National Education (five teachers) are used as a base for that criterion. However, the important point is that it can be thought as this division may cause a kind of "labeling" in the minds of both students and teachers. This labeling carries with different expectations of students in different level based classes (fast learners, slow learners etc.). After a student placed in a level based cluster at the beginning of his/her academic life, rest of his/her studentship is evaluated in terms of that level and evaluations are made related to those criteria [67]. Starting from a similar thought, Boaler, William and Brown [7] define level based clusters as distributing the students with the idea that they have ability levels which are thought as relatively unchangeable and they need an education in line with those levels.

Furthermore, studies emphasize that in case of implementing level based classes, transitivity between levels is quite important. For instance, in a study of Lunn and Ferri [43] in which he investigated the level based classes, he demonstrated that within the period of three years, approximately $75 \%$ of students have not been transferred to a different level although they were in the wrong one. This situation can be interpreted as the fact that students are tend to adapt the level in which they are part of; and as a natural result of this situation, the mobility is limited [59]. On the other hand, in the schools in which different education programs are implemented, transitivity between classes carries with many difficulties in terms of both separating students from their classmates and adapting to a new education program [43]. In the schools in which transitivity between classes provided and level based classrooms are implemented effectively, it has been seen that the students' process of changing classroom is time- consuming and complicated. In the schools in which intra-class level based system is implemented, on the other hand, teachers are in the position of following students every day regularly, and evaluating them in terms of in which group each student would work at best. It is seen in these examples that when decisions are made regarding which student should be placed in which group flexibility and professional autonomy are needed [18].

Five teachers out of nine answered the question "how is the relationship between students in different tracking classes?" as weak and disconnected. In different tracking classes, not only the number of question that solved in classes and the level of difficulty of those questions but also the discipline problems and the class atmosphere change in different aspects. Seven teachers have stated that the discipline problems existed in lower level classes. On the other hand, a teacher has mentioned that different level based classes had different problems. Nine teachers have stated that in different level based classes, the behavior of teachers to students and lectures changed; however, the teacher has claimed that there is no difference in different level based classes. Elementary school is the period of students to join groups. Joining to a peer or play groups of elementary level students is obligation in terms of both requirement and becoming socialized [4]. This requirement is done by leaguing together in both in-class and out of class. However, it is seen that the natural period is interfered when the level cluster is studied. The closest friends are separated on account of the fact that the level difference that is found by standard test. Results of the period of discrimination are unspeaking to the low based classes and not being friends with them. Influences do not occur only in students, it can be said that a presupposition is formed in teachers whether they do not accept or aware of it. Especially in the case that the different teachers give lecture to the different based classes, a hidden competition occurs between the teachers and the criteria of the teachers who give lectures to high level based classes are discussed. In summary, from the angle of teachers, level based class application which is placing students in different classes with discriminator understanding express discriminator and negative pedagogical understanding. Instead of this, it can be suggested that since there is a heterogeneous discriminator, then individualized education in heterogeneous classes can be used according to student's different ways of learning and potentials.

\section{REFERENCES}

[1] Aldan-Karademir, Ç. (2007). Düzey dersliklerinin ilköğretim altıncı sınıf ögrencilerinin fen bilgisi dersine ilişkin akademik başarıları ve benlik saygıları üzerine etkisi [The effect of between class ability grouping on science academic achievement and self-esteem of sixth class students]. (Master's thesis, Adnan Menderes University, Aydın, Turkey). Retrieved from https://tez.yok.gov.tr/UlusalTezMerkezi/

[2] Alpert, B., \& Bechar, S. (2008). School organisational efforts in search for alternatives to ability grouping. Teaching and 
Teacher Education, 24(6), 1599-1612.

[3] Argys, L. M.,Rees, D. I, \& Brewer, D. J. (1996). Detracking America's schools: Equity at zero cost. Journal of Policy Analysis and Management, 15 (4), 623-645

[4] Başaran, E. İ. (1974). Eğitim psikolojisi: Modern eğitimin psikolojik temelleri. [Psychology of education: Psychological foundation of modern education] Ankara. Yargiçoğlu Matbaas1.

[5] Becker, M., Neumann, M., Tetzner, J., Böse, S., Knoppick, H., Maaz, K.,... Lehmann, R. (2014). Is early ability grouping good for high-achieving students' psychosocial development? Effects of the transition into academically selective schools. Journal of Educational Psychology, 106(2), 555-568.

[6] Betts, J. R., \& Shkolnik, J. L. (2000).Key difficulties in identifying the effects of ability grouping on student achievement. Economics of Education Review, 19, 21-26

[7] Boaler, J., Wiliam, D, \& Brown, M. (2000). Students' experiences of ability grouping-disaffection, polarization and the construction of failure. British Educational Research Journal. 26 (5), 631-648.

[8] Boerger, C. J. (2006). Will Ability Grouping the Seventh Grade Students in Math Positively Impact Their BST Scores When They Take the Test in Eight Grade? (Master's Thesis), Winona State University Graduate Education Learning Community Rochester.

[9] Braddock, J. 1990. Alternatives to tracking. Educational Leadership, 47 (7), 76-79.

[10] Broussard, C. A., \& Joseph, A. L. (1998) Tracking: A form of educational neglect. Children \& Schools. 20 (2), 110-120.

[11] Brunello, G., \& Checchi, D. (2007). Does school tracking affect equality of opportunity? New international evidence. Economic Policy, 52, 781-861.

[12] Bygren, M. (2016). Ability Groupings Effects on Grades and the Attainment of Higher Education: A Natural Experiment. Sociology of Education, 89(2), 118-136.

[13] Carborano, W. (2005). Tracking, students' effort and academic achievement. Sociology of Education, 78 (1), $27-49$.

[14] Cheung C. K., \& Rudowicz, E. (2003). Academic outcomes of ability grouping junior high school students in Hong Kong. The Journal of Educational Research, 96 (4), 241-254.

[15] Clarke, M. (2014). Dialectics and dilemmas: psychosocial dimensions of ability grouping policy. Critical Studies in Education, 55(2), 186-200.

[16] Cohen, D., \& Neufeld, B. (1981). The failure of high schools and the progress of education. Daedalus, 110, 69-89.

[17] Çelenk, S., Tertemiz, N., \& Kalayci, N. (2000). İlköğretim programları ve gelişmeler. [Primary schools curriculum and developments] Ankara: Nobel Yayın Dagıtım.

[18] Davies, J., Hallam, S., \& Ireson, I. (2003). Ability groupings in the primary school: issues arising from practice. Research Papers in Education, 18(1), 45-60.

[19] Duru-Bellat, M., \& Mingat, A. (1997). La constitution de classes de niveau dans les colleges: Les effets pervers d'une pratique a' vise'e e'galisatrice [Multilevel classrooms in
French secondary schools: The perverse effects of a supposedly egalitarian practice]. Revue Francxaise de Sociologie, 38(4), 759-789.

[20] Eisenkopf, G. (2005). Heterogene Arbeit: Positive und Normative Aspekte der Qualifikation struktur der Arbeit [Ability grouping and incentives]. Diskussionspapier der Forschergruppe (Nr.: 3468269275) Nr. 05/10, Retrieved from https://kops.uni-konstanz.de/bitstream/handle/123456789/11 873/0510.pdf

[21] Feldhusen, J., \& Moon, S. (1992). Grouping gifted students: Issues and concerns. Gifted Child Quarterly, 36,63-67.

[22] Figlio, D. N., \& Page, M. E. (2002). School choice and the distributional effects of ability tracking: Does separation increase inequality?. Journal of Urban Economics, 51, 497-514.

[23] Gamoran, A., \& Mare, R.D. (1989). Secondary school tracking and educational inequality: Compensation, reinforcement or neutrality. American Journal of Sociology, 94(5), 1146-1183.

[24] Gerring, J. (2007). Case study research: Principles and practices. Cambridge: Cambridge University Press

[25] Gillies, R. (2007). Cooperative learning: Integrating theory and practice. Australia: Sage Publications.

[26] Goldsmith, P. R. (2011). Coleman revisited: School segregation, peers, and frog ponds. American Educational Research Journal, 48, 508-535.

[27] Gömleksiz, M. (1997). Düzey kümeleri: Temeleğitim 2. aşama öğrencileri üzerinde bir araştırma. [Ability grouping: A research on secondary school students] Adana. Baki Kitabevi.

[28] Hallam, S., Ireson, J., \& Davies, J. (2004). Grouping practices in the primary school: what influences change? British Educational Research Journal, 30(1), 117-140.

[29] Hallinan, M., \& Kubitschek, W. N. (1999). Curriculum differentiation and high school achievement, Social Psychology of Education, 3, 41-62

[30] Hamilton, L., \& O'Hara, P. (2011). The tyranny of setting (ability grouping): Challenges to inclusion in Scottish primary schools. Teaching and Teacher Education, 27(4), $712-721$.

[31] Harrison, A.E. (1989). Ability grouping: Practices and perceptions of elementary school teachers. Doctoral Dissertations Available from ProQuest. Paper AAI891736, retrieved from http://scholarworks.umass.edu/dissertations/AAI8917361

[32] Hatch, J. A. (2002). Doing qualitative research in education settings. State University of New York Press.

[33] Hollified, J. (1987). Ability grouping in elementary schools. Retrieved from the ERIC Clearing house on Elementary and Early Childhood Education. ED290542

[34] Holmes C. T., \& Ahr, T. J. (1994). Effects of ability grouping on achievement and self-concept of African-American and White students. The Clearing House, 67 (5), 294-297.

[35] Hornby, G., \& Witte, C. (2014). Preventing School Failure : Alternative Education for Children and Youth Ability Grouping in New Zealand High Schools: Are Ability Grouping in New Zealand High Schools: Are Practices Evidence-Based? Reventing School Failure: Alternative 
Education for Children and Youth, 58(2), 90-95.

[36] Ireson J., \& Maclntyre H. (2002). With-in class ability grouping: Placement of pupils in groups and self-concept. British Educational Research Journal. Vol. 28, 249-263.

[37] Ireson, J., Clark, H. \& Hallam, S. (2002). Constructing ability groups in secondary schools. School Leadership and Management, 22(2), 163-176.

[38] Kim, Y. (2012). Implementing ability grouping in EFL contexts: Perceptions of teachers and students. Language Teaching Research, 16, 289-315.

[39] Kliebard, H. M. (1986). Struggle for the American curriculum: 1893 1958. Boston: Routledge \& Kegan Paul.

[40] Köller, O. (2004). Konsequenzen von Leistungsgruppierungen [Consequences of ability grouping]. Münster, Germany: Waxmann.

[41] Kulik J.A., \& Kulik, C.-L.C. (1992). Meta-Analytic findings on grouping programs. Gifted Child Quarterly. 36 (2), 73-77

[42] Loveless, T. (1998). The tracking and ability grouping debate. Thomas Fordham Foundation

[43] Lunn, J.C. B \& Ferri, E. (1970). Streaming in the Primary School: a longitudinal study of children in streamed and non-streamed junior schools. Slough: National foundation for educational research in England and Wales.

[44] Marsh, H. W. (1987). The big-fish-little-pond effect on academic self- concept. Journal of Educational Psychology, 79, 280-295.

[45] Marsh, H. W. (1991). The failure of high-ability high schools to deliver academic benefits: The importance of academic self-concept and educational aspirations. American Educational Research Journal, 28, 445- 480

[46] Marsh, H. W., Hau, K. T., \& Craven, R. (2004). The big-fishlittle-pond effect stands up to scrutiny. American Psychologist, 59, 269-271.

[47] Marsh, H. W., Seaton, M., Trautwein, U., Lüdtke, O., Hau, K. T., O'Mara, A. J., \& Craven, R. G. (2008). The big-fishlittle-pond-effect stands up to critical scrutiny: Implications for theory, methodology, and future research. Educational Psychology Review, 20, 319-350

[48] Matthews, M. S., Ritchotte, J. A., \& McBee, M. T. (2013). Effects of Schoolwide Cluster Grouping and within-Class Ability Grouping on Elementary School Students' Academic Achievement Growth. High Ability Studies, 24(2), 81-97

[49] Maxwell, J. A. (1996). Qualitative research design: An interactive approach. Thousand Oaks, CA: Sage

[50] McCoach, D. B., O’Connell A. A., \& Levitt, H. (2006). Ability grouping across kindergarten using an early childhood longitudinal study, The Journal of Educational Research, 99 (6), 339-346.

[51] MEB. (2015). Milli Eğitim Bakanlığı [Ministry of National Education (Turkey)] retrieved from url: http://www.meb.gov.tr/mebasp/mebdata/mevzuat/aramalistel eme.asp, retrieved by: 05.05.2015

[52] Miles, M. B. \& Huberman, A. M. (1994). Qualitative data analysis, (2nd ed.) Newbury Park: Ca, Sage.
[53] Mills, R. (1999). Grouping students for instruction in middle schools. ERIC Digest.http://www.ericdigests.org/1999-1/gro uping.html

[54] Mills, C.J., \& Durden, W.G. (1992). Cooperative learning and ability grouping: An issue of choice. Gifted Child Quarterly. 36(1), 11-16

[55] Nevi, C. (1987). In defense of tracking. Educational Leadership, 44 (6), 2426.

[56] Nevi, C. (1991).In Defense of tracking. In J. W. Noll (Ed.) Taking sides: Clashing views on controversial educational issues (pp.286-289). Connecticut: The Dushkin Publishing Group.

[57] Oakes, J. (2005). Keeping track: How schools structure inequality (2nd ed.). New Haven, CT: Yale University Press.

[58] Oaks, J., Rogers, J., \& Lipton, M. (2006). Learning power: Organizing for education and justice. New York, NY: Teachers College Press.

[59] Peak, B., \& Morrison, K. (1988). Investigating banding origins and destinations in a comprehensive school. School Organization, 8(3), 339-349.

[60] Saleh, M., Lazonder, A. W., \& Jong, T. D. (2005). Effects of with-in class ability grouping on social interaction, achievement and motivation. Instructional Science, 33, 105-119.

[61] Seaton, M., Marsh, H. W., Dumas, F., Huguet, P., Monteil, J. -M., Régner, I., et al. (2008). In search of the big fish: Investigating the coexistence of the big-fish-little-pond effect with the positive effects of upward comparisons. The British Journal of Social Psychology, 47,73-103.

[62] Seaton, M., Marsh, H. W., \& Craven, R. G. (2009). Earning its place as a pan-human theory: Universality of the big-fish-little-pond effect across 41 culturally and economically diverse countries. Journal of Educational Psychology, 101, 403-419.

[63] Slavin, R. E. (1990). Achievement effects of ability grouping in secondary schools: A best evidence synthesis. Review of Educational Research, 60 (3), 471-499.

[64] Smith A. E., \& Jussim, L. (1998). Self-fulfilling prophecies, perceptual biases and accuracy at the individual and group levels. Journal of Experimental Social Psychology, 34, 530-561.

[65] Thijs, J., Verkuyten, M., \& Helmond, P. (2010). A further examination of the big-fish-little-pond effect. Sociology of Education, 83, 333-345.

[66] VanderHart, G. P. (2006). Why do some schools group by ability? Some evidence from the NAEP. American Journal of Economics and Sociolog,. 65 (2), 435-462.

[67] Wheelock, A. (1992). Crossing the tracks: How 'untracking' can save America's schools. New York: The New Press.

[68] Zhang, Y., Dongsheng, C., \& Wang, W. (2014). The heterogeneous effects of ability grouping on national college entrance exam performance - evidence from a large city in China. International Journal of Educational Development, 39, 80-91

[69] Zimmer, R. (2003). A new twist in the educational tracking debate. Economics of Educational Review, 22, 307-315. 